\title{
Crop husbandry on naturally compacted soils
}

\author{
W. A. P. Bakermans and C. T. de Wit \\ Institute for Biological and Chemical Research on Field Crops and Herbage (IBS), \\ Wageningen, the Netherlands
}

Received : 20 October 1970

\section{Summary}

The possibilities of crop husbandry on naturally compacted soils are discussed on basis of the results of long-term experiments on sand, clay and peat soils.

A rough-land sowing machine which enables to sow any kind of seed on naturally compacted soils which are covered with remains of previous crops is described.

Detailed herbicide programs are given for various crop rotations and the use of cover crops to suppress weeds and to maintain a good tilth is emphasized. The results of nitrogen fertilization experiments show that in general some more nitrogen is needed on naturally compacted soils than on cultivated soils.

The distribution of organic matter, plant nutrients and roots on naturally compacted and ploughed fields is compared, as well as the yields.

It is concluded that the small grains, maize and many cover crops may be grown on naturally compacted soils without any trouble, but that in case of the growth of sugarbeets, and potatoes - and less for peas and beans - on naturally compacted soils too many risks may be taken, though in many instances no yield depressions are observed.

\section{Introduction}

Soil cultivation is becoming less important as a tool for weed control because of the rapid development of herbicides and to such an extent that it is worth-while to consider under what conditions it is possible to abstain from soil cultivation. To evaluate the possibilities and difficulties of crop husbandry without soil cultivation two extreme situations are being compared. The traditional system of crop husbandry with the customary methods of soil cultivation, such as ploughing, harrowing with disc or spiketooth harrow and between-the-row cultivation is compared with the crop husbandry on naturally compacted soils in which the soil is not cultivated at all, not even for the preparation of a seedbed.

In the case of this 'no-tillage' method the weeds are controlled by means of herbicides and by ecological means, that is by the cultivation of fast-growing, competitive crops which may be harvested for fodder but are in general used as a mulch. Mulch and green manure are considered also necessary to maintain a good structure of the top soil under these conditions and to buffer the fertility status of the soil.

In the course of about ten years husbandry on naturally compacted soils (no-tillage husbandry) has been learned by trial and error. The first experiments were done on sandy soil around the Institute. Here many sowing and weed control techniques have been evaluated without comparing the results with those of more conventional methods. 
For about seven years four permanent experiments have been executed on which half of the plots are tilled normally and the other half are naturally compacted. To obtain as much information as possible on techniques each pair of plots has been grown with a different crop, sacrifying the possibility of judging yield differences statistically.

Most experimental sites were in grassland, so that the naturally compacted plots have not been tilled recently. The plots themselves are so large that the sowing and harvesting operations are done by machine.

The experiments are:

IBS 820 on a loamy sand with $4 \%$ organic matter, in grass from 1948 to 1963, when the experiment was started;

IBS 852 on a low-lying river clay with $11 \%$ organic matter, until 1964 in permanent grass ;

IBS 857 on a low-lying peaty clay soil with $30 \%$ organic matter, until 1964 in permanent grass; and

IBS 390 on a river clay soil with $3 \%$ organic matter, previously in use as arable land, but in grass during the three years before the start of the experiment in 1968.

Apart from these there have been several small and scattered experiments on arable land with sand and clay soil in different parts of the country, the two oldest being ploughed in 1961 for the last time (IBS 619 and 635).

In comparising two techniques of husbandry it is often customary to keep the treatments the same as much as possible, except for the operation under consideration. This is impossible here because the growing conditions are too much affected by the two methods of cultivation. Hence the tilled and the naturally compacted soils were treated as dictated by experience and common sense.

The better trafficability of the naturally compacted fields in spring and autumn was especially used to extend the growing period where this was feasable. Moreover, the time lag in sowing cover crops, unavoidable in the case of conventional tillage, was avoided as much as possible on the naturally compacted fields.

\section{The sowing operation}

The seedbed on compacted soil

The soil is kept covered throughout the year with either a growing crop, harvest refuse (e.g. beet tops), the remains of frozen or killed cover crops or with farmyard manure. As a consequence the first 3 to $8 \mathrm{~cm}$ of the top soil layer is very friable and the more compacted layers below this top layer ensure a reasonable supply of moisture, so that a good seedbed is achieved (Fig. 1). The difficulty is, however, to sow on the proper depth in a soil which is covered with organic matter and not smooth because of the absence of any tillage operations.

When a normal sowing machine is used, the organic material may collect before and under the seed coulters, so that the seed is not brought into the soil and actually covered. Seed not covered properly may dry out or be eaten by birds. To avoid uneven establishment, it is also necessary to cover the seed with soil.

The rough-land sowing machine

A machine which does the sowing job on rough land has been developed in co-operation with the Office of Joint Services (BGD), the Institute of Agricultural Engineering and Rationalization and the construction firm 'Edese Las Industrie'. Fig. 2 shows that 


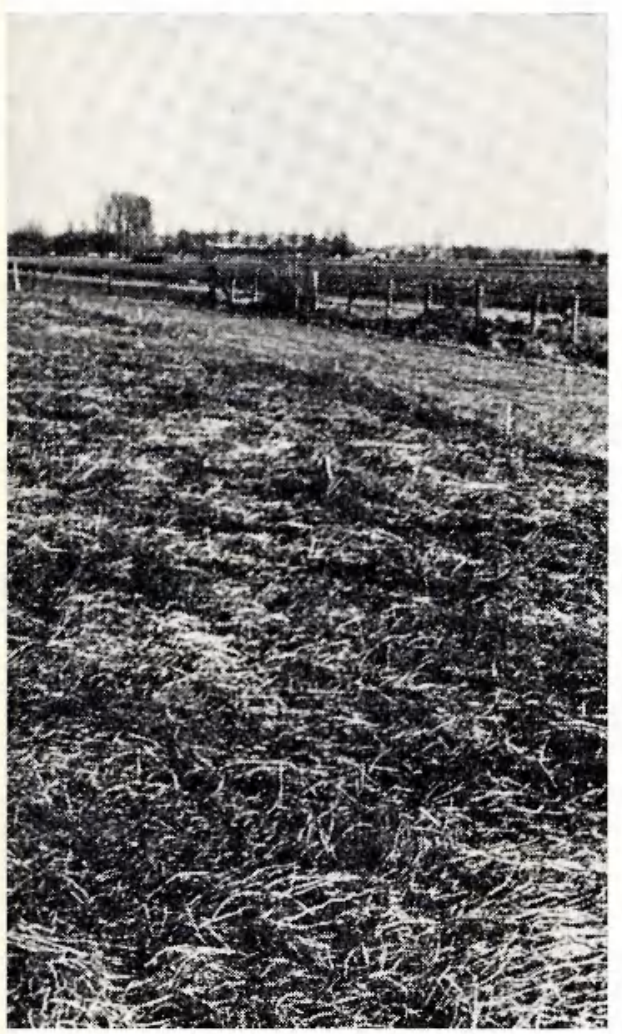

Fig. 1 Seedbed with mulch of frozen vetch.

this machine cuts through the plant remains and mulch with its front disc (A), brings the seed into the soil by means of the two sowing discs, placed in a $\mathrm{V}$ position (B) and closes the seed furrow with small discs (C). These latter discs are mounted on an axle bent in such a way that they may be adjusted parallel to or at a small angle to the direction of sowing and the vertical direction. Small rollers at the back end
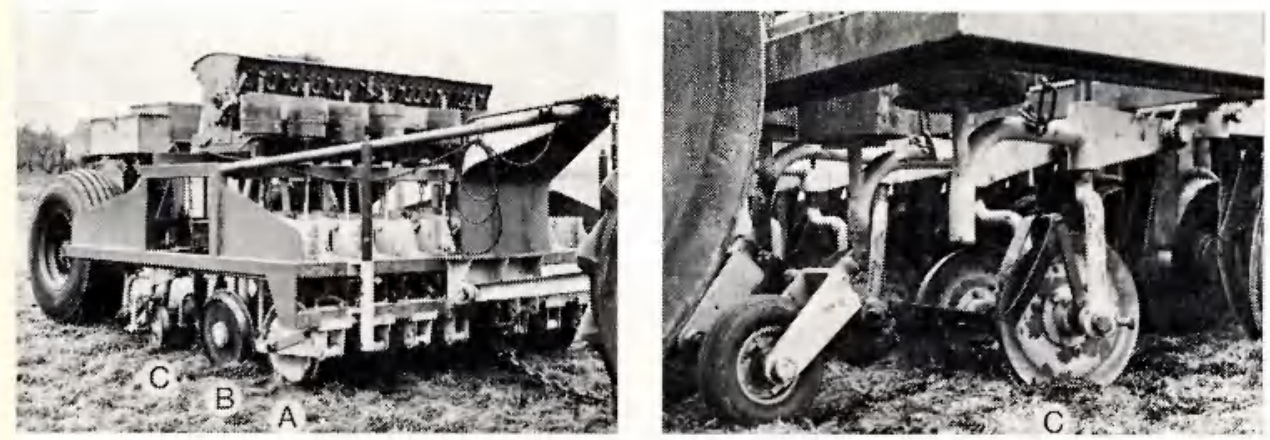

Fig. 2 The rough-land sowing machine. Right: detail of the same machine. 
compact the closed seed furrow (Fig. 2 right). The machine has been constructed in such a way that the soil is disturbed as little as possible in order to avoid germination of weeds and to approach natural compaction as closely as possible.

All parts of the machine are individually suspended so that each moves independently of all others in both directions, even on very uneven land, and thus crawl over the land. Since only rotating elements are in contact with the soil and the discs have large diameters no organic material can accumulate in front of the elements to spoil the operation of the machine and strip the soil.

The working depth of each disc element is regulated separately by means of gauge wheels attached to the discs. These are detachable so that by changing wheels it is possible to sow at a different depth. Even on very irregular soil with tracks and ridges a good depth control is obtained in this manner.

The discs are kept clean of soil by scrapers (Fig. 2 right) and weights are used to obtain the necessary pressure (Fig. 2 left). Although the movement downwards is caused by gravity and not by springs, it appears that a fast driving speed $(10 \mathrm{~km} / \mathrm{h})$ can be maintained without the elements jumping. By means of the hydraulic attachement of the tractor, the machine and all its elements may be lifted. The sowing machine is of course out of work in the lifted position.

The width of the machine is 2 meters and the minimum row spacing is $25 \mathrm{~cm}$ because of the size of the individual sowing elements. To sow closer it is necessary to pass over the land twice.

The low-pressure tires prevent the formation of wheel tracks even on soft soils. The total weight of the machine is $2450 \mathrm{~kg}$ and in transport position $975 \mathrm{~kg}$ of this is carried by the tractor. During sowing the elements carry their own weight of $1550 \mathrm{~kg}$ in total so that the weight carried by tractor and low pressure wheels is reduced to 300 and $600 \mathrm{~kg}$, respectively.

This experimental machine is capable of all the sowing jobs at hand on the trial fields. A commercial machine would not need this wide range of operation and could be of a more simple design.

\section{The sowing operation}

The rough-land sowing machine is capable of all sowing operations on all types of Dutch soil, although it appears advisable to use about $15 \%$ more seed.

After small grains, it is possible to sow in stubble of about $20 \mathrm{~cm}$ height. However fresh straw must be removed because it is too tough for cutting and is pressed into the seed furrow, so that the seeds do not come into good contact with the soil. Thin layers of straw may be cut but then the young plants are often smothered in the straw above the ground. Fresh straw can only be left on the soil when it is chopped into small pieces and regularly distributed.

In this way any following crop may be sown without trouble. However in case straw is left behind the best cover crop is obtained by sowing Italian rye grass as an undercrop, which grows on without any trouble after harvesting of the small grain and chopping of the straw. The chopped straw itself appears to decay very quickly in the often wet grass. After killing the grass in October a beautiful seedbed with a light mulch is available in spring.

Contrary to the difficulties encountered with fresh straw there have been no difficulties with sowing on fields with remains of cover crops, even when these are long and stalky. This material as well as beet tops is decayed practically completely in spring. 


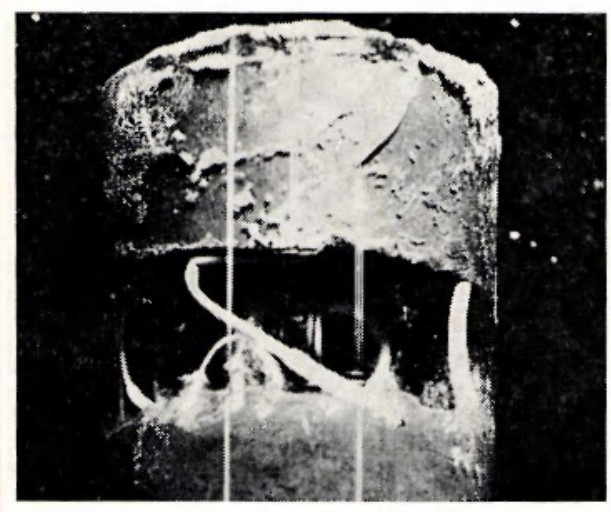

Fig. 3 Seeds of wheat, germinated in a moist hole, cannot penetrate to the soil surface.

Winter wheat seedlings in dead Italian rye grass may be killed by paraquat, used to kill this cover crop a few days before sowing the wheat. This is not the case when the herbicide is applied about three weeks earlier, because then the grass is still younger and decays more rapidly and rain may have washed the paraquat into the soil, where it is adsorbed in an unavailable form and decays.

Larger seeds, such as maize, small grains, peas, vetch and lupin, are easy to sow, and many small seeds such as turnips, cole, rape, marrow-stemmed-kale, flax, Alexandrian and Persian clover and the annual rye grasses do even better in a compacted seedbed. However the emergence of beets and carrots is in general uneven.

It appeared in the wet springs of 1965,1966 and 1970 that the summer crops may be sown appreciably earlier on the naturally compacted soil, because it is practically always in suitable condition to carry the sowing machine. On the other hand it appeared that on heavy, sticky clay soil it was sometimes difficult to pack the seed furrow properly. Although it was closed at the top there remained a hole in which the seeds germinated properly, but the seedlings were not able to penetrate to the surface like the bended one in Fig. 3. Of course the rough-land machine does not work properly under all conditions, but in general it can be said that periods suitable for sowing are extended from hours to days by the use of this machine on naturally compacted soils.

Some experience with other sowing machines

Several firms have been developing sowing machines that are said to work in untilled soil. However these machines often cultivate the soil to some extent and were therefore not used in these experiments but some machines have been evaluated anyhow. The so-called 'sodseeder' with fixed sowing coulters, sometimes used for resowing grassland, is unsuitable because rubbish collects in front of the coulters. The 'rotaseeder of Howard' does a reasonable job when resowing grass, but is unsuitable for the purpose because it is jammed by long and stalky remains of plants and sows at very irregular depth on not completely smooth fields. Moreover, the seeds are not covered with soil when sowing on wide distances.

The 'semavator of Howard' broadcasts the seeds and does a reasonable job with small grains. However it prepares a seedbed and that is not the purpose in these experiments. For 'minimum cultivation' the machine seems very suitable, but in that case a good job is also done by means of a 'fixed-tooth cultivator'. 


\section{The control of weeds and the husbandry of the main crops}

Herbicides with a broad spectrum for killing plants, and with an activity that is lost in contact with the soil (e.g. paraquat) enable a field to be resown directly after weed control (Boone, 1967; Calderbank and Slade, 1966). In many cases it is even possible to use such herbicides after sowing and before emergence of the crop. The control of a cover crop and of plants with reserve organs in the soil (quackgrass, coltsfoot, red sorrel, common horse tail) remains a difficult problem, however.

For good weed control crops that grow rapidly in their early stages are very helpful. Leguminous plants such as beans (Vicia and Phaseolus) and peas often lead to very weedy land, in spite of a good weed control at the time of sowing. Beets, carrots and maize also grow slowly in the beginning, but for these crops selective herbicides ('allbut-killers') are available, so that they may be used to clean the land of weeds. Hemp, potatoes and Brassica species, like winter rape and marrow-temmed kale have a good early growth and suppress therefore weeds. Ecological control is also valuable to keep stubble fields free from weeds. Especially the fast-growing Raphanus sativus var. oleiferus (siletta), Westerwolds rye grass and Italian rye grass are very suitable for this purpose. Besides the use of a suitable crop species good fertilization and regular sowing is necessary to suppress weeds. An open and poor crop always leads to weedy land. The economic aspects of the use of herbicides to control weeds are not considered in the experiments. Without cost considerations herbicides have been used where-ever necessary, with the sole purpose of obtaining a more or less weed-free environment and of killing cover crops. In principle only officially approved herbicides in the officially approved rates have been applied. No direct damage has been observed, apart from some cases where higher than the approved rates were used or herbicides were applied too late.

The impression has been obtained that the naturally compacted soil, with its higher organic matter content in the top, is less sensitive to overdosing than is plowed soil. Where accumulation of herbicides was suspected soil samples were extracted and the extract tested by means of a bio-assay with oat plants. These tests have been negative except in transient periods where atrazin was used in maize, but the maize crop did not succeed and thus did not take up the atrazin.

It has been observed that pennycress (Thlaspi arvense) was less frequent on naturally compacted soil than on tilled soil. But a reduction of weed-seedling population on naturally compacted soil is more the exception than the rule. It may be that the fields are not large enough to prevent immigration of seeds and that the occasional growth of weeds when crops do not succeed, offsets any advantage of naturally compacted soil in this respect.

With very much care a proper choice of crops and a liberal use of a wide spectrum of herbicides, a more or less weed-free environment may be reached on naturally compacted soil, but viewed from a practical standpoint the problem is not solved by any means. Especially under unfavourable weather conditions results may be disappointing.

The methods that have been used and proved sufficiently successfull will be discussed below, amounts of herbicides being quoted in $\mathrm{kg}$ or $\mathrm{l}$ of active ingredient per ha.

\section{The transition of old grassland to arable land}

After the last cut or grazing period the grass is left to regrow for some weeks and then, around the middle of October, treated with $7.5 \mathrm{~kg}$ aminotriazole plus $6.6 \mathrm{~kg}$ 
ammoniumthiocyanate or $68 \mathrm{~kg}$ TCA and one or two weeks later with $1 \mathrm{~kg}$ paraquat. Miaize is then sown in the spring. Broad-leaved weeds are treated with growth hormones two weeks before sowing and at the time of sowing $1 \mathrm{~kg}$ of paraquat is used against running grasses, like quackgrass. By the time that the maize is $10 \mathrm{~cm}$ high, $2 \mathrm{~kg}$ atrazin is used, and if quack grass is present, an aromatic, non-phytotoxic oil is added.

Hemp is also a very suitable crop with excellent weed-suppressing qualities, but cannot be marketed. Summer rape seed may be used also. In all cases it may be necessary to apply paraquat just before sowing.

Summer grains are less suitable because quack grass and other running grasses cannot be controlled. The cultivation of peas and beans invites trouble. In the case of beets it is possible to treat with $1 \mathrm{~kg}$ phenmediphan at a later stage, or to control the quack grass between the rows with paraquat, but this may also involve too much risk.

With little running grass in the pasture, the transition may be made by means of a cover crop and paraquat only. Around the half of July, after one or two harvests, the grass may be left to regrow for about one week and then treated with $1 \mathrm{~kg}$ paraquat. This treatment is repeated at the beginning of August and then turnips or marrow-stemmed kale is sown to be harvested in winter, either by machine or by grazing. If necessary the field is again treated with paraquat and subsequently sown with a small grain in spring, and then treated in the usual way with DNOC and a growth hormone against broad-leaved weeds.

Weed control and the cultivation of cover crops in stubble fields

In the experiments weed control in stubble fields is always combined with the cultivation of a fast-growing, weed-suppressing cover crop used for mulching. To obtain the fast growth and weed-suppressing effect, it is necessary to give liberal amounts (about $100 \mathrm{~kg} / \mathrm{ha}$ ) of nitrogen.

In the presence of quack grass the field is treated directly after harvest with $27 \mathrm{~kg}$ TCA. Possibly after germination of spilled grain and weed seeds $1 \mathrm{~kg}$ paraquat is applied before the sowing of siletta (Raphanus sativus var. oleiferus) (Fig. 4), a crop which stands TCA rather well and suppresses the weakened quack grass by its fast growth. Preliminary research has shown that it may be better to apply $5.5 \mathrm{~kg}$ of TFP instead of the TCA. Quack grass has also been controlled, but with variable success,

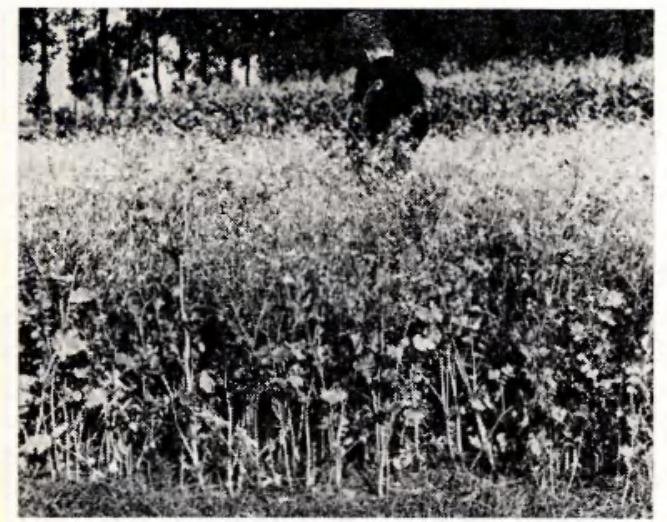

Fig. 4 A crop of Raphanus sativus, var. oleiferus, known as 'siletta' in the Netherlands. 
by the application of $5 \mathrm{~kg}$ dalapon, directly after the harvest, followed by $1 \mathrm{~kg}$ paraquat at the time of sowing siletta or yellow mustard (Sinapis alba).

In the absence of quack grass, but in the presence of coltsfoot (Tussilago farfara) the stubble is treated with $1 \mathrm{~kg}$ of paraquat and Italian rye grass is sown. In the beginning of September the grass is treated with $2 \mathrm{~kg} 2.4-\mathrm{D}$ plus $1 \mathrm{~kg}$ dicamba.

\section{Weed control in winter crops}

After late-harvested crops such as sugar-beets and potatoes, $1 \mathrm{~kg}$ paraquat is applied before sowing winter grains. If possible and necessary the field is treated twice with paraquat at an interval of at least three weeks with the second application being given just before sowing. Pre-emergence application is possible but is in general less effective because during sowing the leaves of many weed plants may be covered with soil and thus be protected against the paraquat. In spring the grain is treated with the usual herbicides against broad-leaved weeds.

If winter grain is sown after siletta the field is treated two weeks before sowing with $0.6 \mathrm{~kg}$ paraquat and $0.4 \mathrm{~kg}$ diquat, but when sown after Italian rye grass, $1 \mathrm{~kg}$ paraquat is used to kill the previous crop. The herbicide treatment should be applied well in advance of sowing to prevent transfer of the paraquat from the dead material to the young wheat plants by direct contact.

Winter rape seed is preferably sown in the stubble of a crop which is harvested early, such as peas. After the harvest of this crop the surface is treated with $36 \mathrm{~kg}$ TCA, followed by $1 \mathrm{~kg}$ paraquat after two weeks and, if necessary, before emergence with $4.5 \mathrm{~kg}$ propachlor. If the main crop is harvested later, as is the case with winter wheat, only $18 \mathrm{~kg}$ of TCA is given because the time for decay of its activity is less.

\section{Weed control in summer crops}

There is not the time for preceeding the summer crop with a cover crop, if in the previous year a late-harvested main crop such as maize, potatoes, or sugar-beet is grown.

If the main crop is harvested before the middle of October, the running grasses and coltsfoot are controlled with $7.5 \mathrm{~kg}$ aminotriazole plus $6.6 \mathrm{~kg}$ ammoniumthiocyanate. When the main crop is harvested later, $68 \mathrm{~kg}$ TCA followed by $1 \mathrm{~kg}$ of paraquat some days later is used instead. In the absence of weeds with reserve organs it suffices to apply paraquat only. After the herbicide treatment farmyard manure is applied to give a winter mulch. If necessary $1 \mathrm{~kg}$ paraquat is applied again before sowing the summer crop.

In general some winter cover crop is available on the fields. If this crop does not freeze sufficiently, it is killed in autumn; rye grasses with $1 \mathrm{~kg}$ paraquat, siletta with $0.5 \mathrm{~kg}$ paraquat plus $0.4 \mathrm{~kg}$ diquat or with $0.5 \mathrm{~kg} 2.4-\mathrm{D}$. An early application is necessary for a sufficient kill and to obtain a decayed mulch by spring. If necessary, $50 \mathrm{~kg}$ TCA is given in November or December and paraquat is again applied before sowing in spring.

Again summer grains are treated with DNOC and growth hormones. Sugar-beets are treated with $2.6 \mathrm{~kg}$ pyrazon plus $2.5 \mathrm{~kg}$ propham and then once or twice with $1 \mathrm{~kg}$ phenmedipham. Grasses may be controlled at this stage with an interrow treatment of paraquat.

Peas and French beans are only grown on weed-free land, for example after maize, and treated before sowing with $1 \mathrm{~kg}$ paraquat. Peas are treated during growth with 
$1.25 \mathrm{~kg}$ dinoseb acetate, whereas beans may be treated before emergence with $1.8 \mathrm{~kg}$ dinoseb acetate plus $0.47 \mathrm{~kg}$ monolinuron.

Carrots may be sown on weed-infested land after treatment with $1 \mathrm{~kg}$ paraquat. During early growth grasses and broad-leaved weeds are controlled with 6001 selective aromatic oil per hectare, followed after three weeks by $2 \mathrm{~kg}$ linuron.

Maize is treated before sowing with $1 \mathrm{~kg}$ paraquat whereas $2 \mathrm{~kg}$ atrazine is given when the crop is $10 \mathrm{~cm}$ tall. In the presence of green quack grass the addition of 201 non-phytotoxic oil improves the killing appreciably. Interrow application of paraquat has been successful when used at the time that the crop is about $50 \mathrm{~cm}$ high.

\section{Crop rotation and harvesting difficulties}

As has been said, most experiments were started on permanent grassland in order to profit from the stable soil structure and the high humus content and to avoid the transient state of lower yields such as is known to occur during the transition from arable land to permanent grassland (Voisin, 1960).

Apart from this start crop rotation has not been scheduled, because experience with many crops had to be built up and the weed infestation often determined the choice of the crop, especially in the early years.

Potatoes have not been grown on the main experiments because the harvesting operation is an intensive soil cultivation in itself. However it was shown in other experiments that this crop grows very well without ridging on naturally compacted soil. The tubers are formed very close to the seed potato but grow partly above the soil, so that too many green tubers are harvested. On heavy clay soil some soil cultivation with a rotating cultivator was necessary at the time of planting to obtain sufficient soil for ridging. Machine harvesting was then possible without any trouble.

Sugar-beets and carrots were harvested by hand except on one experiment with larger fields. It appeared that mechanical harvesting of beets from naturally compacted soil is possible, although some more breakage and root damage has been observed.

\section{Diseases and pests}

There has been very little trouble with pests and diseases on the trial fields. On the naturally compacted, mulched soils there was in general somewhat more trouble with wireworms, leather-jackets, cutworms, flea-beetles, snails and other bugs. Sometimes it appeared necessary to mix the seed with formaldehyde or to use hepta spray.

Considerable trouble has been given by birds, mice and moles, a trouble which has been partly due to the relatively small size of the fields and their situation in grassland areas. Birds were especially a nuisance during ripening and during early growth when they uproot just germinating plants to get at the seed. Like birds, mice appear to feel at home on the fields covered with plant remains or thick mulches and some naturally compacted soils are more or less cultivated by moles. Whether this is due to the presence of more earth-worms in these soils has not been examined as yet.

\section{Fertilization}

\section{$K$ and $P$ fertilization}

All fertilizers are broadcasted. To avoid unnecessary differences between treatments, the $\mathrm{P}$ and $\mathrm{K}$ fertilization has been the same on the cultivated and naturally compacted soil. Since not much harm can be done by these fertilizers, their dosages have been chosen on the large side. 
Under the humid conditions that prevail in the Netherlands, fertilizers in the top soil are in general readily available and as a consequence no nutrient shortages have been observed, with one exception. On a sandy soil in the spring of 1970 , P deficiency appeared in maize during a dry period just after emergence. The P-deficiency symptoms were somewhat more severe on the naturally compacted than on the plowed soil, but they disappeared on both after some rain.

\section{$N$ fertilization and yield responses}

More attention has been given to the nitrogen fertilization. Although the ploughed and uncultivated fields received the same amount, one third of each field was set aside each year for a simple nitrogen experiment with four treatments: low, normal, high and very high dosage of $\mathrm{N}$. This nitrogen experiment returned to the same site after three years. Aftereffects of the dosages were studied during the first year after the differential application.

A detailed analysis of the results of these nitrogen experiments is impossible because they were executed without replication and yields varied sometimes considerably because of damage by weather, birds and game. The results of the experiments on which the crops succeeded are summarized in Fig. 5-11.

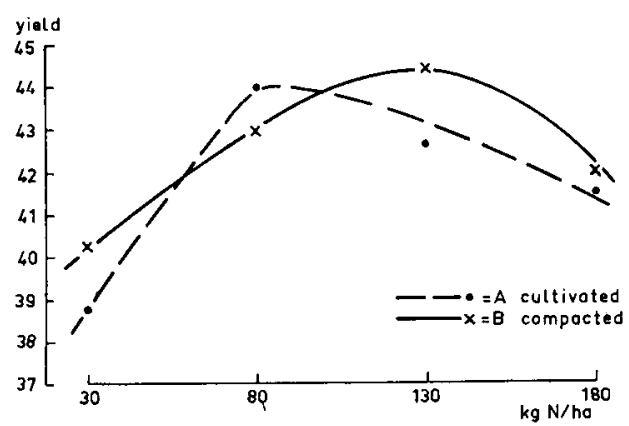

Fig. 5 Average kernel yields of small grains in $100 \mathrm{~kg} / \mathrm{ha}$ of 22 experiments.

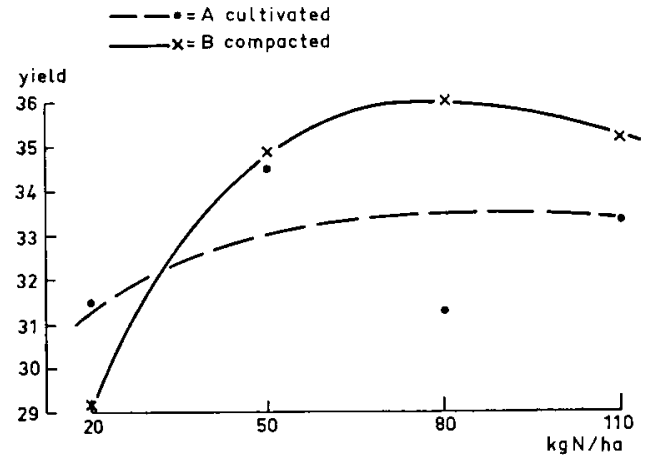

Fig. 7 Average kernel yield of peas in $100 \mathrm{~kg} /$ ha of 6 experiments.

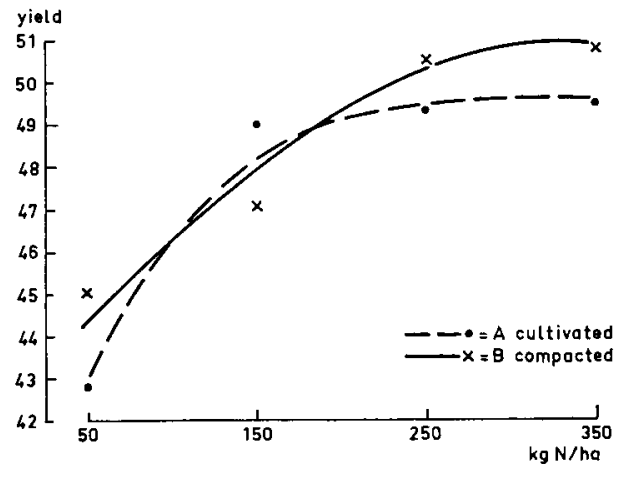

Fig. 6 Average fresh weight of sugar-beets in $1000 \mathrm{~kg} / \mathrm{ha}$ of 4 experiments.

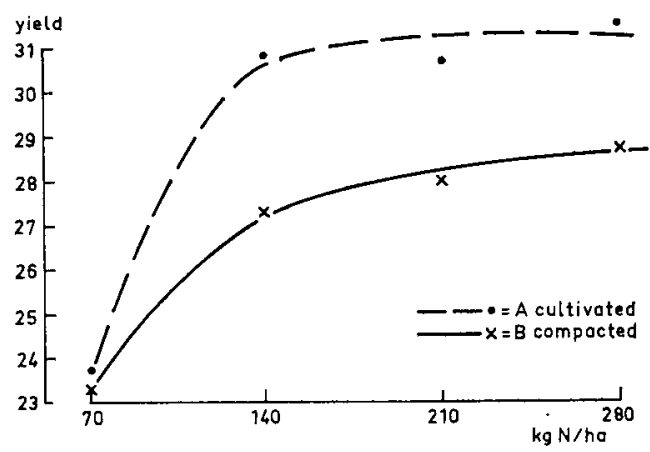

Fig. 8 Average kernel yield of winter rape seed in $100 \mathrm{~kg} / \mathrm{ha}$ of 6 experiments. 
Table 1 Yield of potatoes $(100 \mathrm{~kg} / \mathrm{ha})$ on light, sandy soil

\begin{tabular}{ccc}
\hline $\begin{array}{c}\text { N-fertilization } \\
(\mathrm{kg} N / \text { ha })\end{array}$ & Cultivated soil & $\begin{array}{c}\text { Naturally } \\
\text { compacted soil }\end{array}$ \\
100 & 351 & 277 \\
200 & 367 & 375 \\
300 & 382 & 381 \\
\hline
\end{tabular}

In Fig. 5 the kernel yields of rye, wheat, oats and barley in 22 experiments are given as a function of the applied amount of nitrogen. It seems that small grains do need and can stand $20-40 \mathrm{~kg} \mathrm{~N} / \mathrm{ha}$ more on naturally compacted soil.

The results of four experiments with sugar-beets are summarized in Fig. 6 . On the naturally compacted soil about $50-100 \mathrm{~kg} \mathrm{~N} /$ ha more is needed, but this seems to result also in a somewhat higher yield than on the ploughed soils.

The results of 6 experiments with peas are given in Fig. 7. The crop on the naturally compacted soil needs at least $30 \mathrm{~kg} \mathrm{~N} / \mathrm{ha}$ more, this difference in $\mathrm{N}$ fertilization again being accompagnied by a higher yield.

The results of 6 experiments with winter rape seed are summarized in Fig. 8. It appears that this crop needs somewhat more nitrogen, but that in spite of this the yields on the naturally compacted soil are lower.

Only a few data are available for potatoes. The result of one experiment after three years without cultivation, is summarized in Table 1, indicating that this crop yields less with low $\mathrm{N}$ application on compacted soil.

Some of the experiments have also been analysed as to the nitrogen content and uptake. Fig. 9 presents the results of four experiments with maize. It is seen in the fourth quadrant of this figure that the nitrogen uptake on the compacted soil is distinctly higher than on the cultivated. However it appears in the first quadrant that this higher uptake did not result in a yield increase. Hence the yields of maize on the cultivated and compacted soil were the same, as shown in the second quadrant.

The results of a similar analysis of oats and barley mixtures (Fig. 10) show that the nitrogen uptake was the same for the two husbandry methods. In these particular experiments the yield did not respond to nitrogen fertilization at all, in spite of the increased uptake with increased $\mathrm{N}$ supply.

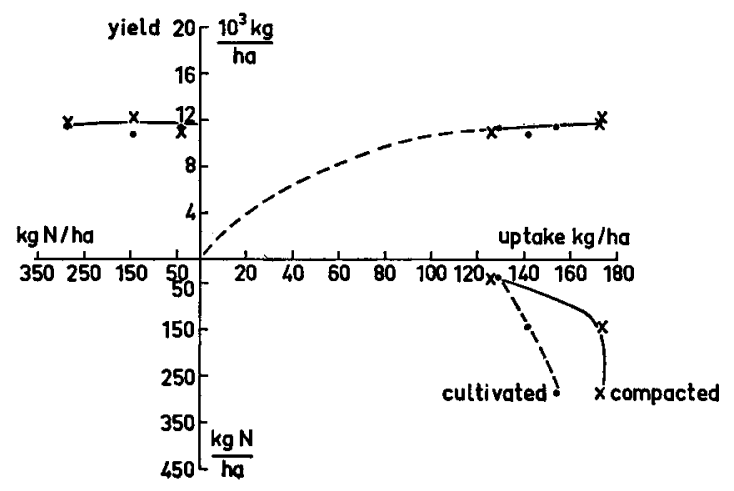

Fig. 9 Yield and nitrogen uptake of four experiments with maize. For explanation, see text. 


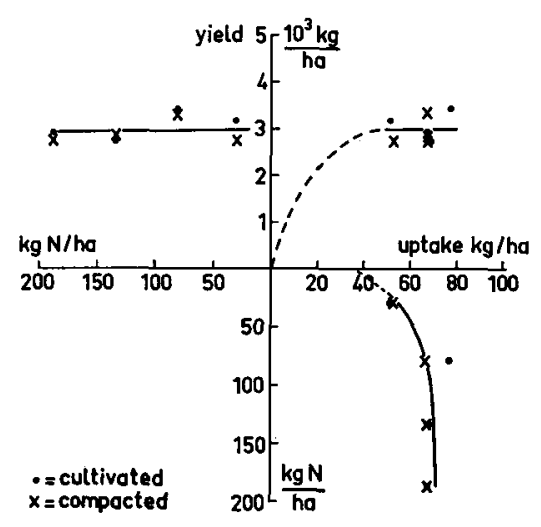

Fig. 10 Yield and nitrogen uptake of three experiments with oat/barley mixtures. For explanation, see text.

Fig. 11 represents the yield response of oat/barley mixtures after rye (IBS 820) and maize (IBS 857), one year after fertilization with $30,80,130$ and $180 \mathrm{~kg} \mathrm{~N} / \mathrm{ha}$ and $30,100,180$ and $260 \mathrm{~kg} \mathrm{~N} / \mathrm{ha}$, respectively. No aftereffect is apparent on the cultivated soil, but on the compacted soil the yields increased with increased application rate of nitrogen during the previous year. Aftereffects of nitrogen fertilization have also been observed with sugar-beets, as is illustrated in Table 2.

International Chemical Industries (ICI) applies on their experimental fields in the Netherlands some more nitrogen on the compacted soil and the more so, as the clay content is higher. Although the wisdom of this practice is confirmed by our and other experiments the reasons for doing so are not well established (e.g. Milton and le Merre, 1967; Kahut, 1968). More nitrogen may be needed to compensate for the somewhat thinner stand, the somewhat less developed root system or the presence of weeds. Apart from this it may be that on the compacted soil the applied nitrogen is to a larger extent incorporated in the organic material and that mineralization of the nitrogen proceeds at a somewhat slower rate. Such an assumption would explain the aftereffects (Fig. 11) and possibly the higher uptake of maize on compacted soil, which is much longer on the field than oats (Fig. 9 and 10).

It may be noted in this respect that L. Rixhon in Gembloux (personal communication) observed a distinct yield increase after ploughing soil which had been under compacted cultivation during three years, compared with the yield on normally ploughed soil. Such yield increases are also observed after ploughing ley pastures. Rixhon is of the

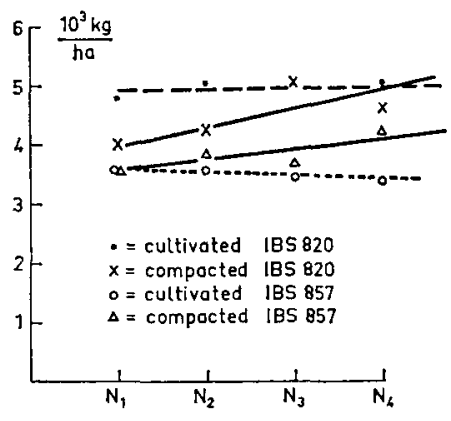

Fig. 11 The aftereffect on the yield of oat/barley mixtures of various $N$ applications to the previous crop. 
Table 2 Fresh yields of beets and tops $(1000 \mathrm{~kg} / \mathrm{ha})$ in response to $\mathrm{N}$-fertilization $(\mathrm{kg} \mathrm{N} / \mathrm{ha}$ ) in the previous year

$\begin{array}{crc}N \text { in previous year } & \text { Cultivated soil } & \text { Compacted soil } \\ 50 & 102 & 108 \\ 250 & 94 & 110 \\ 350 & 99 & 123\end{array}$

opinion that, starting from arable land, in the first few years more nitrogen is needed on the naturally compacted soils.

In the present experiments, originally in grass, a decreased need of nitrogen on the ploughing fields was not very evident during the first years, but an increased yield after ploughing was observed on some fields which had been naturally compacted for 5 years.

The distribution of nutrients and organic matter

All fertilizers and all organic materials are applied at the top of the soil, whereas the roots of the crops explore the deeper layers. Hence in the absence of soil cultivation it is likely that the top layer shows an enrichment of all applied materials and elements, which are not readily transported downwards with the water. In the presence of soil cultivation this accumulation in the top layer is counterbalanced by mixing the soil. Any differences in this respect show up only in due course, so that stratified analyses have been done only after at least five years of experimenting. The ploughed
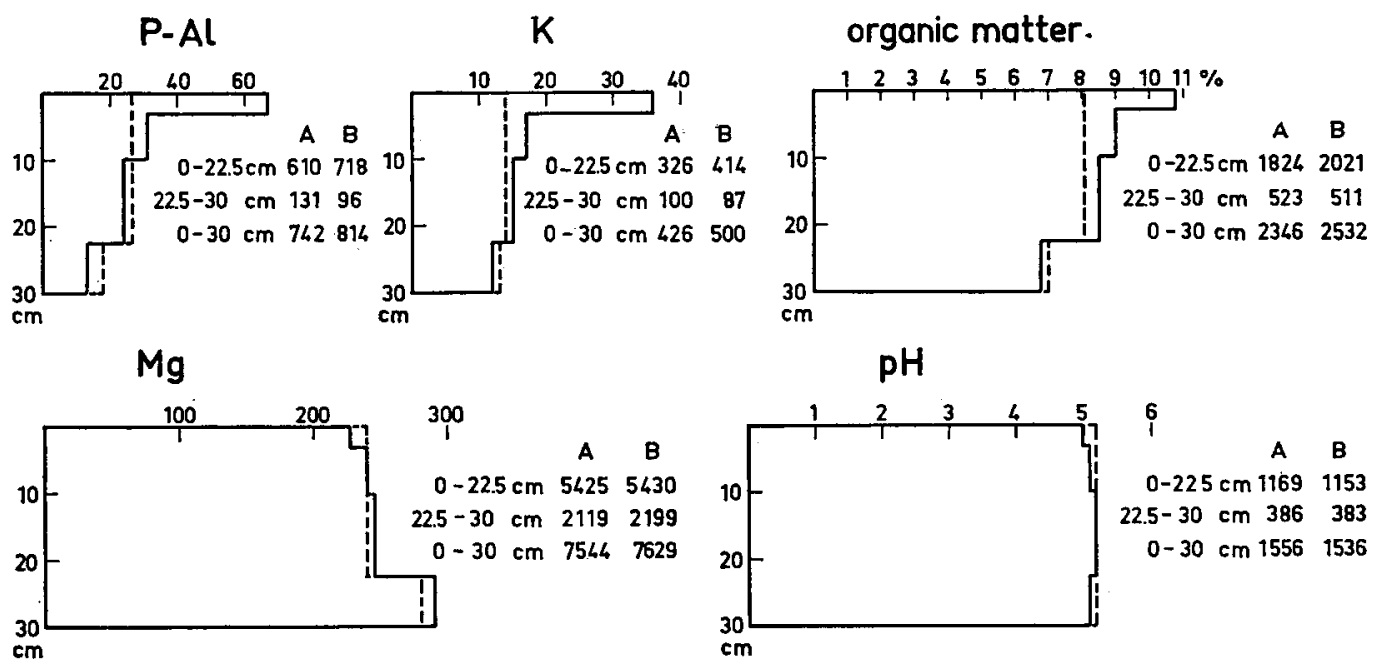

\section{$---=$ A cultivated}

$-1=B$ compocted

Fig. 12 Average distribution in 22 experiments of plant nutrients, $p H$ and organic matter on cultivated $(A)$ and naturally compacted $(B)$ soil, after five years. $K$ is in $\mathrm{mg} K_{2} \mathrm{O} / 100 \mathrm{~g}$ and $\mathrm{Mg}$ in $\mathrm{mg}$ $\mathrm{MgO} / \mathrm{kg}$. The numbers along the graphs present the surface areas of the histograms. 


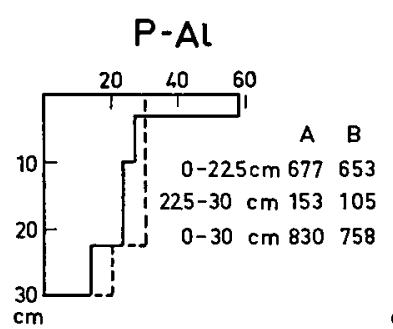

$\mathrm{Mg}$

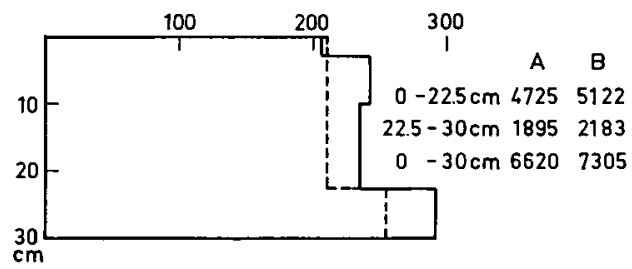

organic matter

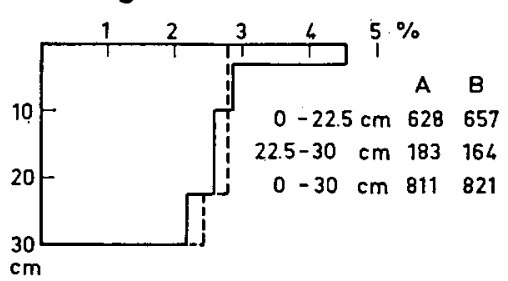

$\mathrm{pH}$

\section{---- A cultivated \\ $-=B$ compacted}

Fig. 13 Distribution of plant nutrients, $p H$ and organic matter content on cultivated (A) and compacted (B) soil. Same as Fig. 12, but for 10 experiments on soils low in organic matter.

soil has been sampled in two layers, the first being from $0-22.5$ centimeter which is the average plowing depth and the second from 22.5 to $30 \mathrm{~cm}$. The naturally compacted soil has been sampled in the $0-3 \mathrm{~cm}, 3-10 \mathrm{~cm}, 10-22.5 \mathrm{~cm}$ and $22.5-30 \mathrm{~cm}$
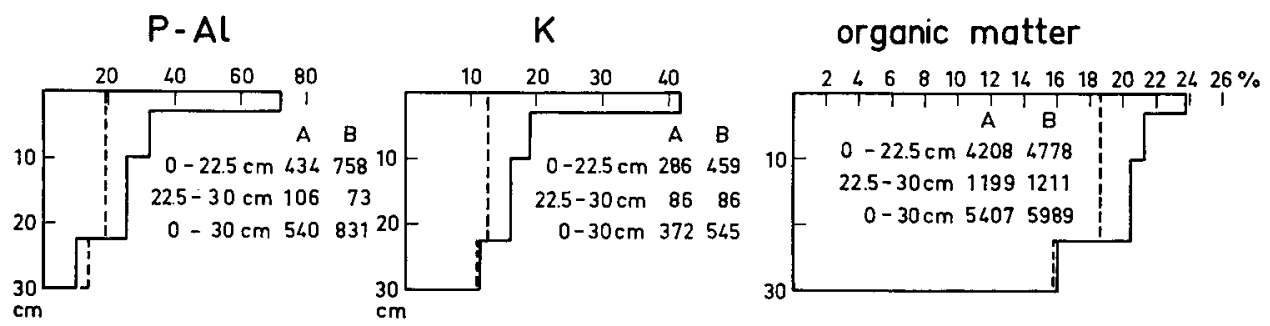

$\mathrm{Mg}$

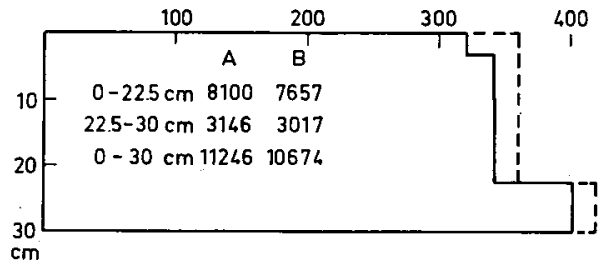

\section{$\mathrm{pH}$}
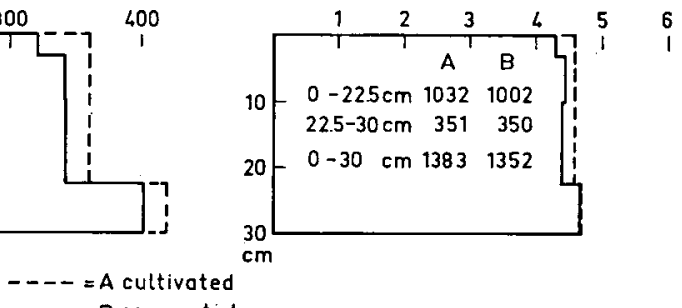

$=B$ compacted

Fig. 14 The same as Fig. 12, but for 7 experiments with a high organic matter content in the soil. 
layers, it being assumed that any effect of accumulation would show up especially in the top few centimeters of the soil. The soil characteristics that have been determined are the $\mathrm{pH}$, the $\mathrm{Mg}$ and $\mathrm{K}$ content, and the $\mathrm{P}-\mathrm{Al}$ number (ammonium-lactate-acetate method) according to the standarized procedures of the Dutch Soil Testing Laboratory. The average results for 22 fields are summarized in Fig. 12. Potassium, the available phosphate and the organic material are accumulated to a considerable extent in the top layer of the compacted soil, whereas the $\mathrm{pH}$ and the $\mathrm{Mg}$ content is lower in the top layer and higher in the lower layers. During the experimental period, no $\mathrm{Mg}$ and $\mathrm{Ca}$ was given and since these elements are subject to leaching, depletion of the top layer is reasonable.

In principle the data allow calculation of the amount of 'available' nutrients in the various layers. A comparison should be done by taking into account the volume weights of the soil and the characteristics of the various analysis methods. However in this stage no sufficient data have been collected to allow for more than a cursory inspection of the trends.

This is done first by comparing the surface of the graphs under the solid lines for the compacted (B) and the dotted lines for the cultivated soil (A) in Fig. 12. These surfaces are presented in the same figure for the layers of $0-22.5 \mathrm{~cm}, 22.5-30 \mathrm{~cm}$ and 0-30 $\mathrm{cm}$, coinciding approximately with the ploughed layer and the compacted subsoil on the ploughed soil. It appears that the amount of potassium and the available phosphate and the total amount of organic material is higher on the compacted soil than on the cultivated soil. Hence, the elements $\mathbf{P}$ and $\mathbf{K}$ have been leached or fixed less on the compacted soil and less organic material has been decayed. There is no reason to suppose that the removal of $\mathrm{K}$ and $\mathrm{P}$ by harvesting has been different for both treatments.

A further inspection of the data shows a clear distinction between the soils with an organic matter content of 3-5\% (sand and river-clay) and a content of $12-30 \%$ (peat and river-clay rich in humus). The average results for these two groups are shown in Fig. 13 and 14.

The distribution of the materials and elements is the same for both groups of soil. However it appears that on soils with a high organic matter content, the total amounts (as measured by the surface of the histograms) of $\mathrm{P}, \mathrm{K}$ and organic matter are the highest on the compacted fields (B), whereas the differences with the ploughed fields (A) are negligible on soils with a low organic matter content, except for the potassium. The significance of these differences may be judged from the graphs of Fig. 15, where the surfaces of the histograms of the $0-30 \mathrm{~cm}$ layer on the ploughed soil (A) are given as a function of these surfaces on the compacted soil (B) for individual experimental fields.

If it is assumed that the production of new organic matter on the compacted soil is higher and its decomposition slower than on the ploughed soil, a difference in content should have been observed on both types of soils, rich and poor in organic matter. However, if it is assumed that the organic matter originally present in the soil, decays more rapidly on the ploughed fieids, a difference between compacted and ploughed soil should only be observed on the soil types, rich in (relatively easily decomposable) organic matter. This latter is the case, so that we assume tentatively that differences in organic matter content in our experiments are mainly due to different decay rates. However further research is necessary to evaluate all processes involved.

A relative decrease in total amount of available phosphate appeared to occur only in the ploughed fields with a high organic matter content. Since the organic phosphates 

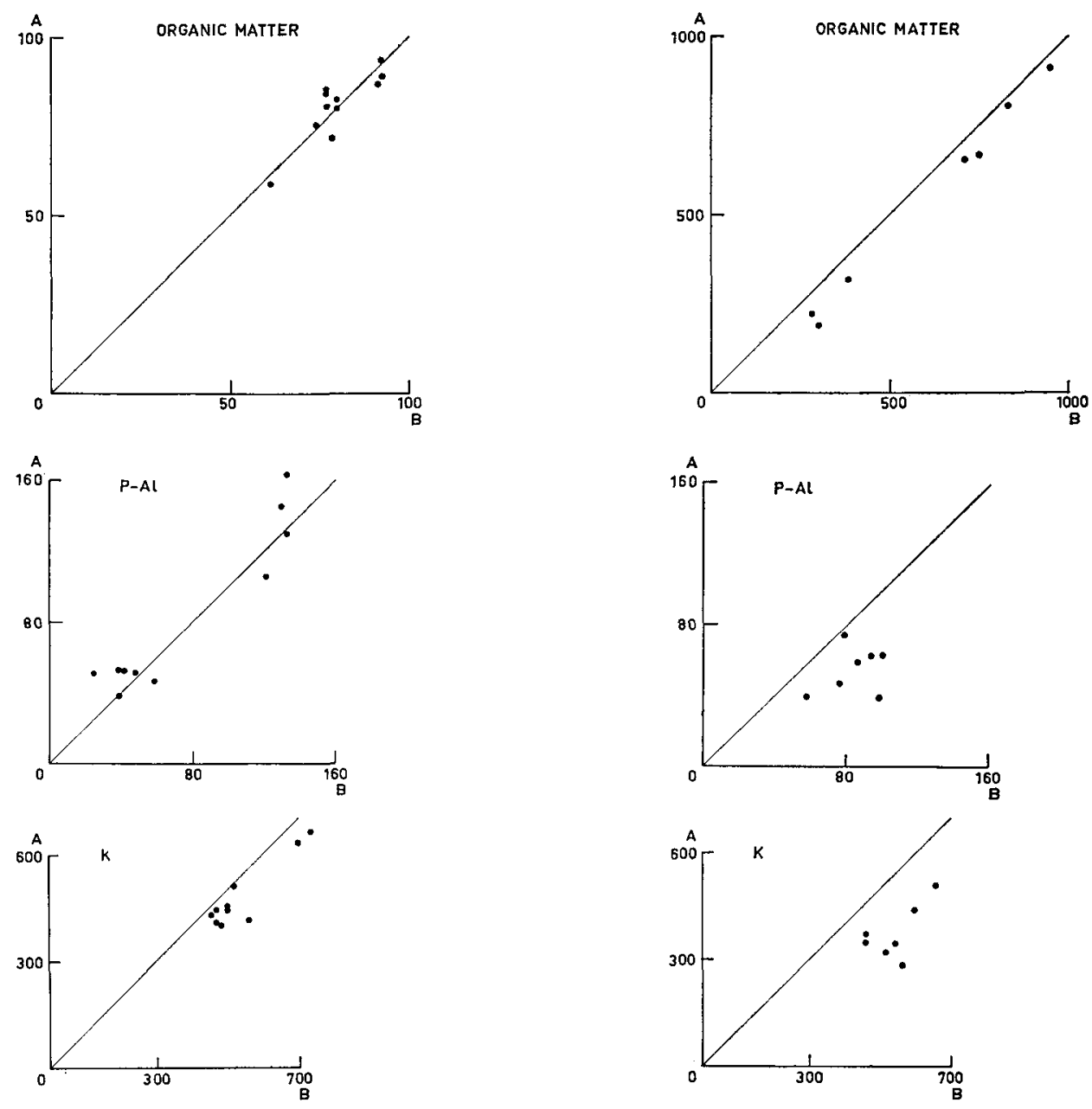

Fig. 15 The surface of histograms as in Fig. 13 and 14, on cultivated soil (A) as a function of the surface on the compacted soil $(B)$ for individual experimental fields. The left and right hand graphs concern fields with a low and high organic matter content, respectively.

only partly contribute to the value of the P-Al number, this particular behaviour of the phosphate is difficult to interpret without additional information. As far as the results on the soils low in organic matter are concerned, it may safely be concluded that although phosphates are accumulated in the top-most portion of the soil, the total amount available is not affected.

The total amount of potassium is less on the ploughed than on the compacted soil, on soils both rich and poor in organic matter. This may be explained by mass transport downwards because of ploughing and subsequent more leaching. 


\section{Soil structure and root architecture}

The physical characteristics of the soils as influenced by the two methods of husbandry are discussed by Ouwerkerk and Boone (1970) elsewhere in this journal (p. 247 sqq.), so that it suffices here to make some general remarks on soil structure and to discuss some observations on the development of roots.

First, a profile description for compacted and cultivated soils is given, together with the root density profile as observed on a vertical plane.

Fig. 16 concerns a sandy soil (IBS 820) grown with rye and fertilized with $80 \mathrm{~kg} \mathrm{~N} / \mathrm{ha}$. On the cultivated soil the ploughed layer of about $20 \mathrm{~cm}$ is reflected distinctly by the root density, whereas in the compacted soil dense rooting is restricted to the upper $8 \mathrm{~cm}$. The remainder of the compacted and cultivated soil has only a few roots and then mainly in places where roots occurred formerly.

Because the densely rooted upper soil layer is smaller, the amount of roots on the
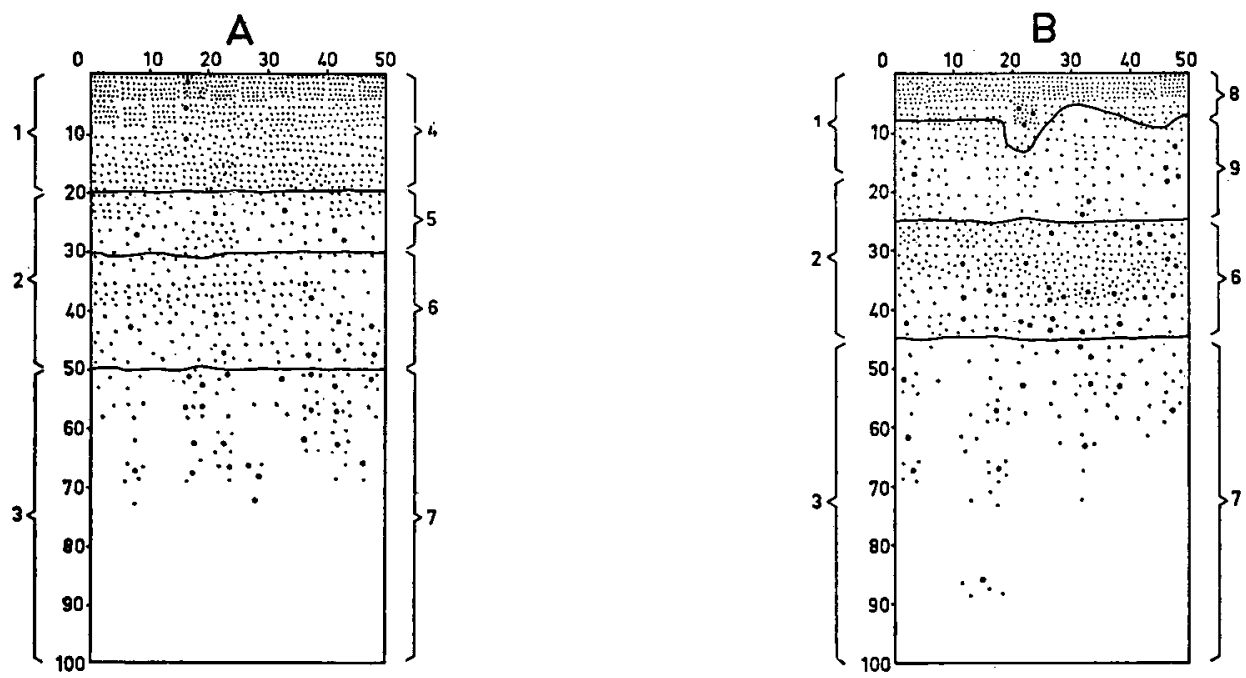

Fig. 16 Soil profile and root-density of rye on cultivated (A) and compacted (B) sandy soil (IBS 820).

A. Texture and organic matter:

$1=$ Slightly loamy moderately fine sand, moderately humous $(4 \%$ organic matter, $6 \%<16 \mu \mathrm{m})$.

$2=$ Slightly loamy moderately fine sand, moderately poor in humus $(2 \%$ organic matter, $4 \%$ $<16 \mu \mathrm{m})$.

$3=$ Moderately coarse sand.

Structure:

$4=A 4 A 3 a^{1}$ II-III $1^{1 / 2-2} 2^{1 / 2}$ subangular blocky and granular elements, with a good porosity.

$5=$ F2bhk compact structure.

$6=G 1 C$ spongy structure with meso- and micropores (pore diameter $<100 \mu \mathrm{m}$ ).

$7=$ Sand in open packing.

B. Texture and organic matter:

1-3: see $A$

Structure:

6-7: see $A$

$8=A 4 A 3 a^{1}$ II-III $1^{1 / 2}$ subangular blocky and granular elements with a good porosity.

$9=G I C$ (F2bhk) spongy structure with meso- and micropores going to a compact structure. 
W. A. P. BAKERMANS AND C. T. DE WIT
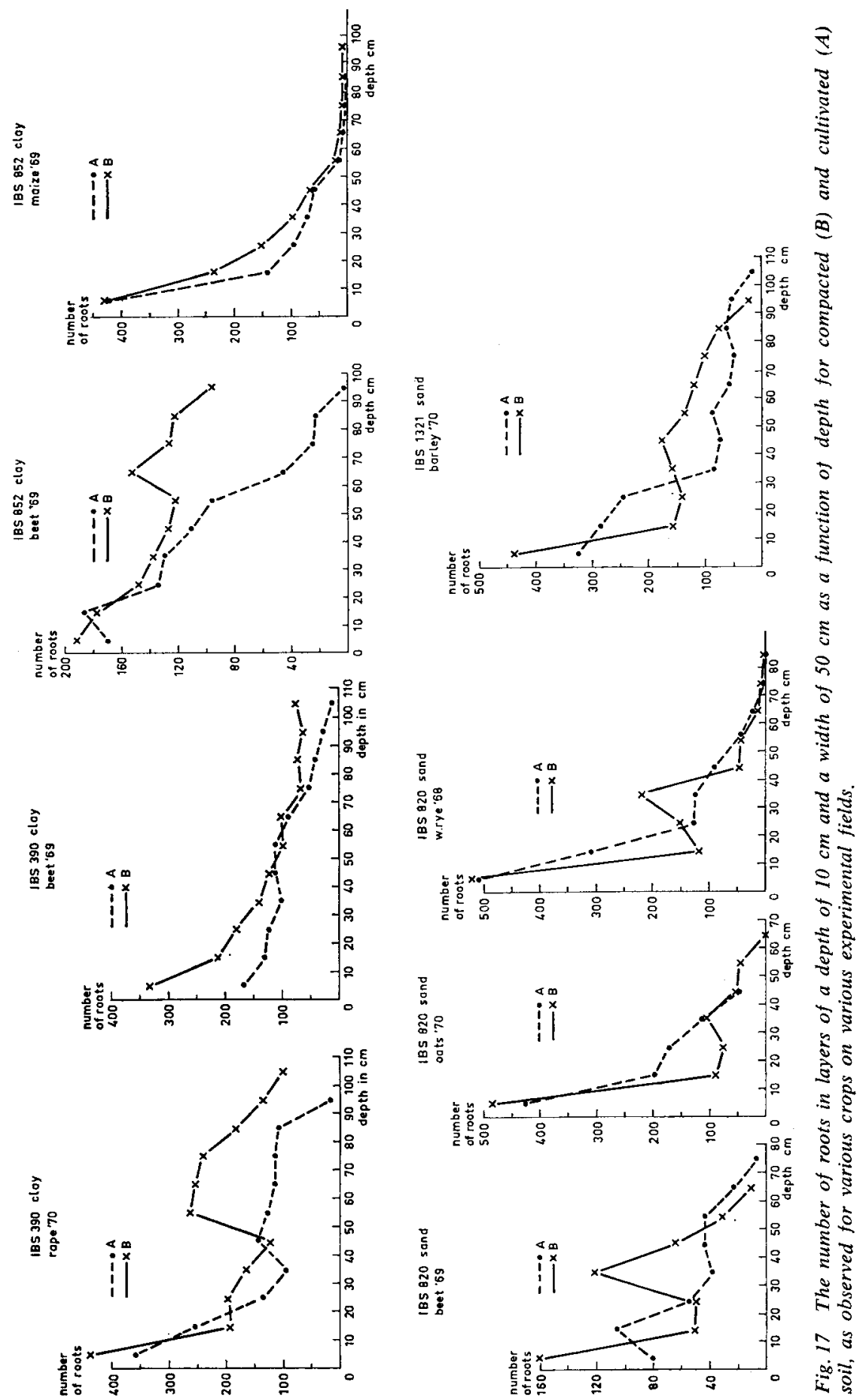

Neth. J. agric. Sci. 18 (1970) 
CROP HUSBANDRY ON NATURALLY COMPACTED SOILS

Table 3 Seed yield of rye (100 kg/ha) on sandy soil (IBS 820)

\begin{tabular}{ccc}
\hline $\begin{array}{l}\text { Fertilizer } \\
(\mathrm{kgN} / \mathrm{ha})\end{array}$ & Cultivated soil & Compacted soil \\
& & \\
30 & 31.4 & 25.5 \\
80 & 44.3 & 42.5 \\
130 & 47.5 & 48.0 \\
180 & 44.7 & 46.0 \\
\hline
\end{tabular}

compacted soil is less than on the cultivated soil, but in spite of this the yield was not smaller, at least in the presence of sufficient nitrogen (Table 3 ).

Graphs of the number of roots per $10 \mathrm{~cm}$ as a function of depth are given in Fig. 17. They show that the top $10 \mathrm{~cm}$ of the naturally compacted soil always contain more roots than of the cultivated soil, which is undoubtedly associated with the good tilth and nutritional status. However the layers from $10-20$ and also from $20-30 \mathrm{~cm}$ contain less roots because they are more compact, at least on the sandy soils. But from $30 \mathrm{~cm}$ onwards, the compacted soil is rooted with at least as great density as the cultivated soil.

To what extent the type of soil limits the possibilities of crop husbandry on naturally compacted soils in the long run is not known as yet. It seems that on peat, löss and clay soils with a good structure in the subsoil no difficulties will be encountered. However, on one loamy sand with little stability of aggregates, the rooting below $15 \mathrm{~cm}$ was negligible after two years without tillage and under those circumstances serious yield depressions were observed. Moreover it appeared that sugar-beets branched profusely on other loamy sands when grown on soil which was not cultivated for 7 years; the yield was then only $30 \%$ of normal (Fig. 18). It is likely, that especially the mechanical resistance limited rooting and caused abnormal development of the beets.

Clay soil remains plastic in the presence of sufficient water and cracks in its absence, and this ensures practically normal root development under all conditions, although still somewhat more branching of beets occurred on the compacted soil. The harvestibility was therefore somewhat less and damage somewhat more in comparison with the beets on the cultivated clay soil.

In spite of the uncultivated soil being more compact than the cultivated, pool formation and stagnation of water did not occur more often, but this problem of non-stationary movement in layered soils is analysed in more detail by means of a simulation study of van Keulen and van Beek (1971, in press).

Little is known about the influence of herbicides on soil flora and fauna, apart from

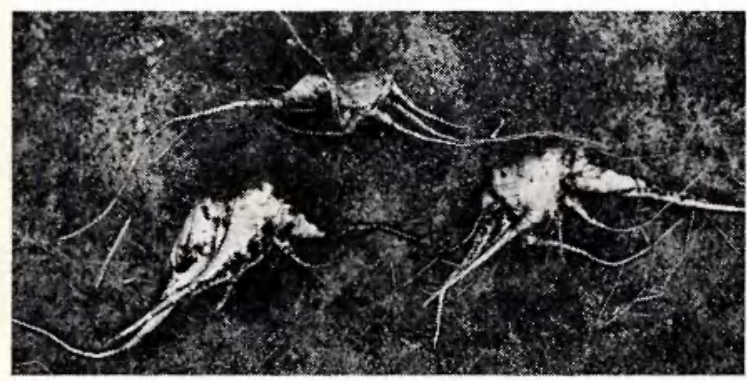

Neth. J. agric. Sci. 18 (1970)
Fig. 18 Sugar-betets grown on compacted loamy sand (IBS 619). 
some aspects of this problem that will be discussed by van de Bund (1970) in this journal (p. 308 sqq.). It is known that mulching promotes the growth of earth-worms and that a considerable number of them may be killed by ploughing and other cultivation practices (Graff, 1964). Hence it is expected that the number of earth-worms is higher on the compacted soil and this seems to be confirmed by the observation that moles seem to prefer living there. However actual counts of earth-worm populations have not been made as yet.

Research on the temperature aspects is in progress. It is obvious that a thick mulch works as a blanket to keep the soil warm in autumn and cold in spring and this is one of the reasons that thick mulches are avoided in spring.

A last important aspect is that stubbles and decaying plant parts shield the soil against wind and water erosion and conserves a good tilth of the top soil; advantageous effects of this have been observed occasionally.

\section{Yield of crops and practical possibilities}

The emergence and early growth of the crops is in general somewhat retarded on the compacted soil, but this is in most cases not reflected in the yield. As far as the retarded growth is due to early sowing, it is often more than compensated later on.

It appeared that crops on compacted soils need some more nitrogen but then yield at least equal amounts as on cultivated soils (with the possible exception of rape seed). This is confirmed in Fig. 19 where the yields on the cultivated and compacted soils of crops are presented. The observational points appear to scatter along the $45^{\circ}$ line. It may be observed that the yield level on the trial fields is not too high, but this is a consequence of the initial policy of selecting soils which were originally in permanent grass and therefore not too suitable for arable land.

Only the yield of fields where the crop succeeded with both treatments are given in
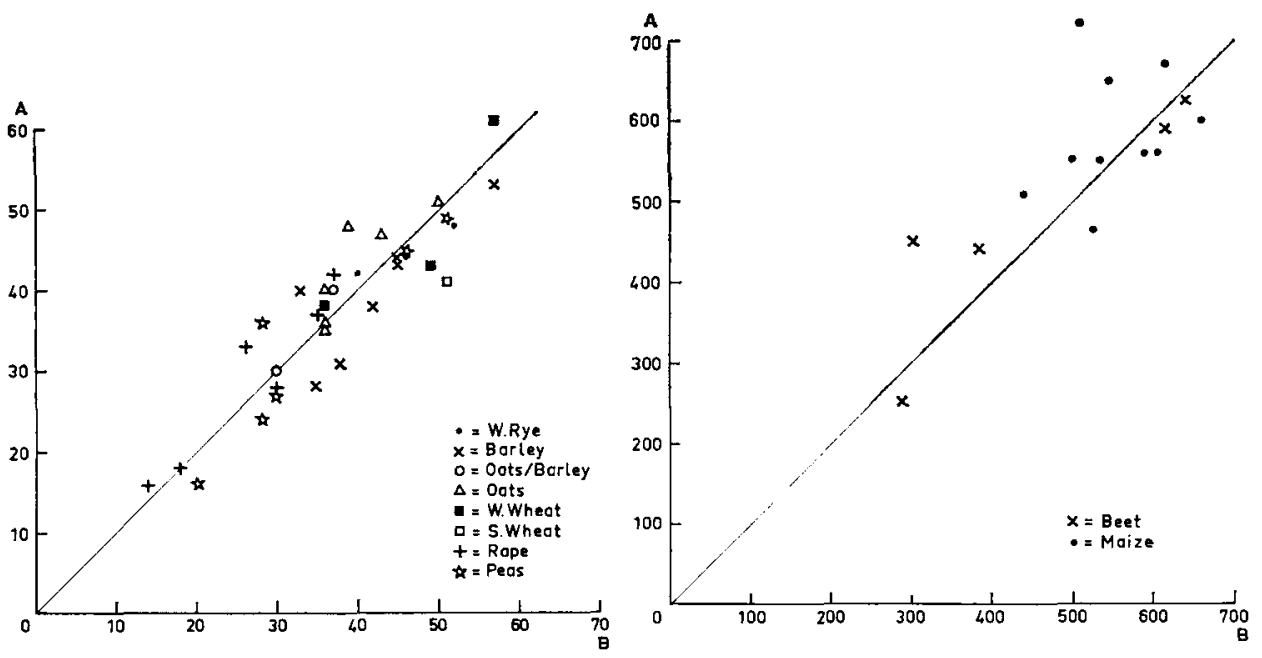

Fig. 19 The yields (in $100 \mathrm{~kg} / \mathrm{ha}$ ) of all established crops on cultivated soil (A) as a function of those on compacted soil $(B)$. 
these graphs, but it should be taken into account that there have been a considerable number of failures. These failures were partly due to the circumstance that much had to be learned about sowing and weed-control techniques and that always considerable risks have been taken. After all, it was the purpose of the trial to make a survey of possibilities and not to avoid risks. Such failures still occur, but may be avoided in the future.

Except for some soils with a 'panning' subsoll, the growth of small grains, maize and green manures such as siletta, kale, Italian rye grass and turnips involves hardly any particular risks on compacted land, whereas the yields are at least as large as those obtained by traditional methods of cultivation.

Crop husbandry on naturally compacted soils may be adapted therefore in regions and on fields with a crop rotation that does not contain crops such as sugar-beets and potatoes. The advantages are then: better trafficability, more days suitable for working, possibility of early sowing, conservation of moisture in the spring because of light mulches, less erosion, more versatile use of soils with a labile structure and a saving on the costs of cultivation.

To what extent these advantages are offset by the costs of herbicides remains to be seen, but this depends also to a large extent on the price policy of chemical compagnies and the extent of the weed problem.

In regions and on fields where also potatoes, sugar-beets, peas, beans, etc. are grown, the crop husbandry on compacted soils, as discussed in this paper, may involve too many risks. It still occurs that, in spite of good emergence and weed control, crops do not grow, sometimes because of the compactness of the soil, but sometimes without apparent reason at all. However there are no indications that it is necessary to be very puritanical as to the use and avoidance of the plow and the best policy seems to use the plow and other soil cultivation implements in situations where their need is proven and otherwise to avoid these implements where possible.

It is this pragmatic approach that is more and more adapted by farmers.

One example is the growth of sugar-beets on sandy soils, sensitive to wind erosion. Rye is sown on normally cultivated soils in the previous autumn and then killed in spring with paraquat. Beets are subsequently sown in the killed rye without any cultivation, so that wind erosion is prevented. On 'not panning' soils it may be attempted even to adapt a rotation with small grains and sugar-beets without any cultivation.

\section{Acknowledgment}

The authors are indebted to Mr J. W. J. Loeters and Mr A. F. C. M. Schellekens of the Horticultural Advisory Service for Matters Relating to the Soil, for the description of root architecture and soil structure.

\section{References}

Boon, W. R., 1967. The quarternary salts of bipyridyl - a new agricultural tool. Endeavour 26:27-33. Boone, F. R. \& H. Kuipers, 1970. Remarks on soil structure in relation to zero-tillage. Neth. J. agric. Sci. 18 (1970) 262-269.

Bund, C. F. van de, 1970. Influence of crop and tillage on mites and springtails in arable soil. Neth. J. agric. Sci. 18(1970) 308-314.

Calderbank, A. \& P. Slade, 1966. The fate of paraquat in plants. Outlook Agric. 5: 55-60. 
Graff, O., 1964. Untersuchungen über die Bodenfauna im Ackerboden. Insttitut für Humuswirtschaft, Braunschweig-Völkenrode.

Kahut, G., 1968. Säen ohne Pflügen? Mitt. Deut. landw.Ges, 83: 463.

Keulen, H. van \& C. G. E. M. van Beek, 1971. Water movement in layered soils. Neth. J. agric. Sci. 19 (in prep.).

Millou, J. \& J. le Merre, 1967. Essais de culture sans labour de blé d'hiver et d'orge de printemps 1965-'66. C.r. hebd. Séanc. Acad. Agric. Fr. 2: 178-188.

Voisin, A., 1960. 'Years of depression' in reseeded pastures. In: Better grassland sward. London, 1960, p. $95-129$. 